Journal of Physical Science, Vol. 29(Supp. 2), 27-38, 2018

\title{
Particle and Crystallite Size Characterisation of Lead Titanate Derived from Solid-state Reaction Method
}

\author{
Dony Hidayat Al-Janan, ${ }^{*}$ Rahmat Doni Widodo, Rusiyanto and \\ Leonardus Dimas Bima Saputra \\ Mechanical Engineering Department, Engineering Faculty, \\ Universitas Negeri Semarang, Jawa Tengah 50229, Indonesia \\ *Corresponding author: aljanan@mail.unnes.ac.id
}

Published online: 30 July 2018

To cite this article: Al-Janan, D. H. et al. (2018). Particle and crystallite size characterisation of lead titanate derived from solid-state reaction method. J. Phys. Sci., 29(Supp. 2), 27-38, https://doi.org/10.21315/jps2018.29.s2.3

To link to this article: https://doi.org/10.21315/jps2018.29.s2.3

\begin{abstract}
Lead titanate $\left(\mathrm{PbTiO}_{3}\right)$ ceramic was produced by solid state reaction via a vibratory ball milling machine and subsequent heat treatment. The effect of milling time on the particle and crystallite size of $\mathrm{PbTiO}_{3}$ powder was investigated. Powder samples were studied using particle size analyser (PSA). The annealing process was up to $1,000^{\circ} \mathrm{C}$ and the products were examined by X-ray diffractometer (XRD) to determine phase formation and crystallite size. It was found that the average particle size of powder initially increased due to laminated layers formation and then decreased to an asymptotic value of $\sim 0.8 \mu \mathrm{m}$ as the milling time extended even to a relatively longer time. Single-phase $\mathrm{PbTiO}_{3}$ were achieved at $600^{\circ} \mathrm{C}$ for $1 \mathrm{~h}$ holding time of annealing temperature. Annealing the sample of the particles at $1,000^{\circ} \mathrm{C}$ resulted in a dense compact and promoted the formation of particles containing nanocrystallites. The crystallite size of $\mathrm{PbTiO}_{3}$ increased as the function of temperature of annealing process.
\end{abstract}

Keywords: Lead titanate, particle size, crystallite size, solid state reaction, annealing

\section{INTRODUCTION}

Ferroelectrics are materials with reversible spontaneous polarisation. ${ }^{1-4} \mathrm{Lead}$ titanate $\left(\mathrm{PbTiO}_{3}\right)$ is one of the fundamental ferroelectric materials with an $\mathrm{ABO}_{3}$ compound structure called perovskite and the highest spontaneous polarisation among all the ferroelectric perovskites. ${ }^{5-14}$ According to the first-principle calculations on ferroelectric perovskites, hybridisation between the electronic 
states of A or B atoms and the oxygen atoms is essential for ferroelectricity. $\mathrm{PbTiO}_{3}$ has highest tetragonal distortion $(\mathrm{c} / \mathrm{a} \approx 1.063)$ among all members of the perovskite's family. This tetragonal distortion corresponds to the highest spontaneous polarisation among all the ferroelectric perovskites. Perovskite-type $\mathrm{PbTiO}_{3}$ has a high spontaneous polarisation of $86 \mu \mathrm{C} \mathrm{cm}^{-2}$, Curie temperature of $364^{\circ} \mathrm{C}-490^{\circ} \mathrm{C}$, a relatively low permittivity, a large pyroelectric coefficient $(250$ $\mu \mathrm{C} \mathrm{cm}^{-2} \mathrm{~K}^{-1}$ ) and small dielectric constant. ${ }^{5,10,15-17}$ The dielectric constant increased in the annealing range of $450^{\circ} \mathrm{C}-750^{\circ} \mathrm{C}$. This trend is due to the increased grain size and higher crystallinity with annealing temperatures. ${ }^{18}$ The values of saturation polarisation $\left(P_{s}\right)$, remanent polarisation $\left(P_{r}\right)$ and coercive field $\left(E_{c}\right) \mathrm{PbTiO}_{3}$ are 13.1 $\mu \mathrm{C} \mathrm{cm}^{-2}, 3.2 \mu \mathrm{C} \mathrm{cm}^{-2}$ and $5.1 \mathrm{kV} \mathrm{cm}^{-1}$, respectively. Because of their character, ferroelectrics are widely used in many applications: the ferroelectric randomaccess memory field, pyroelectric infrared sensor, electro-optic devices, insulator gates in metal-insulator-semiconductor diodes, capacitors, transistor, piezoelectric actuators, high frequency ultrasonic transducers and so on. ${ }^{19-22}$

The $\mathrm{PbTiO}_{3}$ property within its applications depends on several aspects: the purity of materials indicated in stoichiometry number; and microstructure that consists of phase, particle's size and then crystallite's size. To obtain the stoichiometry, particle and crystallite size $\mathrm{PbTiO}_{3}$, different preparation methods have been introduced such as co-precipitation, emulsion or hydrothermal treatment sol-gel and spark plasma sintering sonochemical, besides the conventional solid-state reaction of mixed oxides or mechanical alloying.,4,69-12,16,20,23-35 All methods will produce varying microstructures, processes and then manufacture temperature. The processing time must be determined for quick process and the better quality of final product; it has higher purity in single phase, and the particle and crystallite are formed in nanometer size. Chattopadhyay et al. conducted a detailed study on the influence of particle size on the ferroelectric properties of lead titanate. ${ }^{36}$ Studies revealed that size effects are important only below $100 \mathrm{~nm}$. The usual method for producing the fine nanocrystalline materials is mechanical alloying and milling by a ball-milling technique, which has also been adapted into the preparation of lead titanite. The technique is considered simple and less costly for producing very fine particles. In this study, mechanical alloying and milling method has been developed to produce the fine nanocrystalline materials of $\mathrm{PbTiO}_{3}$ ceramics. Finally, the results were assessed on material characterisation consisting of particle and crystallite size. 


\section{EXPERIMENTAL}

$\mathrm{PbTiO}_{3}$ was obtained from the mixture of lead (II) carbonate $\left(\mathrm{PbCO}_{3}\right)$ and titanium (IV) oxide $\left(\mathrm{TiO}_{2}\right)$ powders by using high-energy ball milling and heat treatment processes. Stoichiometric quantities of the analytical-graded precursors $\mathrm{PbCO}_{3}$ and $\mathrm{TiO}_{2}$ with purity better than $98 \%$ were mixed and milled in a vibratory ball mill up to $60 \mathrm{~h}$. The weight ratio of balls to milled material was 1:10. After milling process, the diameter sizes of examined powder particles were determined using particle size analyser (PSA) Malvern ZS Nanoseries. Phase analysis and crystallite size of milled powders were carried out using the X-ray Philips diffractometer equipped with $\mathrm{CuK \alpha}$ radiation. The X-ray diffraction (XRD) patterns were recorded by "step-scanning" method. The powders were annealed in the electric chamber furnace $($ Nabertherm $\mathrm{N} 31 / \mathrm{H})$ at $500^{\circ} \mathrm{C}, 600^{\circ} \mathrm{C}, 700^{\circ} \mathrm{C}, 800^{\circ} \mathrm{C}, 900^{\circ} \mathrm{C}$ and $1,000^{\circ} \mathrm{C}$ in the air under atmosphere pressure up to $1 \mathrm{~h}$. The Rietveld analysis was performed applying High Score Plus program that is an updated version for Rietveld refinement with PC and mainframe computers. The pseudo-Voigt function was used in describing the diffraction line profiles at Rietveld refinement. The crystallite sizes for $\mathrm{PbCO}_{3}, \mathrm{TiO}_{2}$ and also $\mathrm{PbTiO}_{3}$ phases were estimated using Williamson-Hall method. ${ }^{37}$ Intensity data during scanning of $2 \mathrm{~s}$ was taken for each step of the diffraction angle $0.005^{\circ}$. Diffraction peak width $(B)$ is given by Equation 1 and the mean crystallite size $(D)$ obtained from Equation 2:

$$
\begin{aligned}
& B=\frac{0.9 \lambda}{D \cos \theta}+\eta \tan \theta \\
& B \cos \theta=\frac{0.9 \lambda}{D}+\eta \sin \theta
\end{aligned}
$$

where $\lambda$ is the $\mathrm{X}$-ray wavelength, $\eta$ is the strain in the materials and $\theta$ is the Bragg angle, while the peak width $B$ is obtained after the correction due to instrument broadening according to Equation 3:

$$
B=\sqrt{B_{0}^{2}-B_{S}^{2}}
$$

$B_{o}$ is the Full Width at Half Maximum (FWHM) of the test sample, and $B_{s}$ is the FWHM standard samples that used silicon (Si). 


\section{RESULTS AND DISCUSSION}

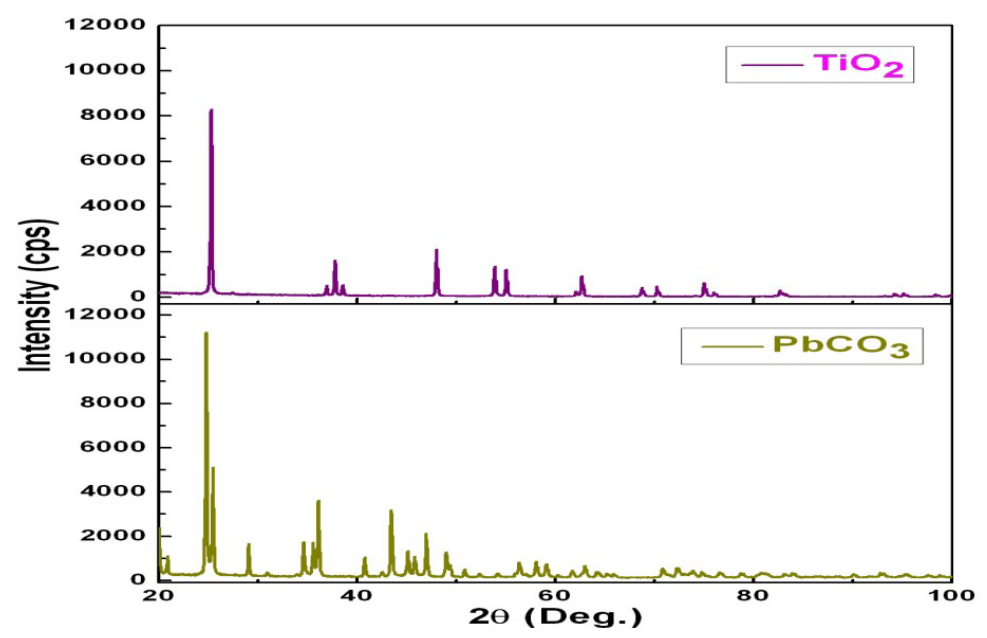

Figure 1: XRD patterns of $\mathrm{TiO}_{2}$ and $\mathrm{PbCO}_{3}$ precursors.

The diffraction patterns of $\mathrm{TiO}_{2}$ and $\mathrm{PbCO}_{3}$ precursors shown in Figure 1 which were matched with diffraction patterns of $\mathrm{TiO}_{2}$ and $\mathrm{PbCO}_{3}$ in Inorganic Crystal Structure Database (ICSD) number 98-009-6946 and 98-016-6089 respectively. Based on the Rietveld analysis, the crystal system of $\mathrm{TiO}_{2}$ and $\mathrm{PbCO}_{3}$ are tetragonal and orthorhombic respectively.

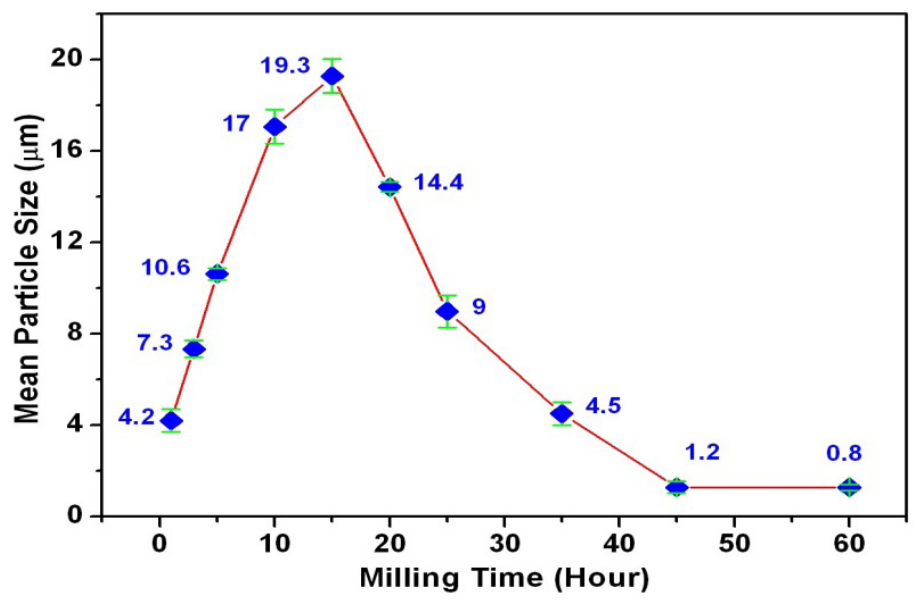

Figure 2: The mean particle size of $\mathrm{TiO}_{2}$ and $\mathrm{PbCO}_{3}$ mixture with milling time. 
Figure 2 shows results of evaluation for mean particle size of $\mathrm{TiO}_{2}$ and $\mathrm{PbCO}_{3}$ mixture up to $60 \mathrm{~h}$ of milling. All sample powders went through the four stages of the mechanical alloying process, namely: (a) initial stage; (b) intermediate stage; (c) final stage; and (d) completion stage. ${ }^{38}$ It shows that the mean particle sizes of mechanically milled $\mathrm{TiO}_{2}$ and $\mathrm{PbCO}_{3}$ mixture in initial or early stages of milling are characterised by the increase in the mean particle size due to incorporation of particles of component compounds. The mean particle size of the material increased from $4.2 \mu \mathrm{m}$ to $17 \mu \mathrm{m}$ at duration $1 \mathrm{~h}$ to $10 \mathrm{~h}$ of mixing. The core compounds experienced cold weld, namely the integration of the two particles of the basic compounds to form a close bond between the particles as a consequence of the ball mill impact. The process of impact between ball mills continuously occurred. The largest mean particle size were achieved after $15 \mathrm{~h}$ milling times, while the mean particle size of $\mathrm{TiO}_{2}$ and $\mathrm{PbCO}_{3}$ mixture is $\sim 19 \mu \mathrm{m}$. As the milling time extended beyond $15 \mathrm{~h}$, the mean size towards a settled value decreased progressively. Long terms of mechanical treatment during advanced stages of mechanical alloying caused the particles to experience embitterment due to accumulation of internal stresses. ${ }^{39}$ Continuous plastic deformations of the brittle particles caused further reduction in particle size towards an average value of $\sim 0.8 \mu \mathrm{m}$ and eventually settled down to that value even when the deformation continued to grow after the duration of $60 \mathrm{~h}$ milling time at completion stage.

The comparison of diffraction patterns of $\mathrm{TiO}_{2}$ and $\mathrm{PbCO}_{3}$ mixture after $1 \mathrm{~h}$, $5 \mathrm{~h}, 10 \mathrm{~h}, 25 \mathrm{~h}, 40 \mathrm{~h}$ and $60 \mathrm{~h}$ of milling process is shown in Figure 3. Identification of the diffraction peaks ensured that all peaks matched with that of $\mathrm{TiO}_{2}$ and $\mathrm{PbCO}_{3}$ phase.

Figure 4 illustrates the evaluation of mean crystallite size in milled particles after milling process based on XRD patterns using Williamson-Hall method. Figure 4 shows the ball milling process for $60 \mathrm{~h}$ in a mixture of $\mathrm{TiO}_{2}$ and $\mathrm{PbCO}_{3}$ lead to a decline in the value of the average crystallite size. The average size of the $\mathrm{TiO}_{2}$ crystallites decreased not so significantly exponentially with time. In contrast to $\mathrm{TiO}_{2}$, after mechanical alloying of $60 \mathrm{~h}$, the crystallite size of $\mathrm{PbCO}_{3}$ decreased significantly about 1.5 times smaller. It shows that the process of milling up to $60 \mathrm{~h}$ resulted in a more brittle and easily shattered $\mathrm{PbCO}_{3}$ when compared with $\mathrm{TiO}_{2}$. The mechanical milling process caused a decrease in the crystallite size of tested phases and led to homogenising of the milled mixture. The mean crystallite size of $\mathrm{TiO}_{2}$ and $\mathrm{PbCO}_{3}$ phases diminished to $87 \mathrm{~nm}$ and $80 \mathrm{~nm}$, respectively of the milling time up to $60 \mathrm{~h}$. 


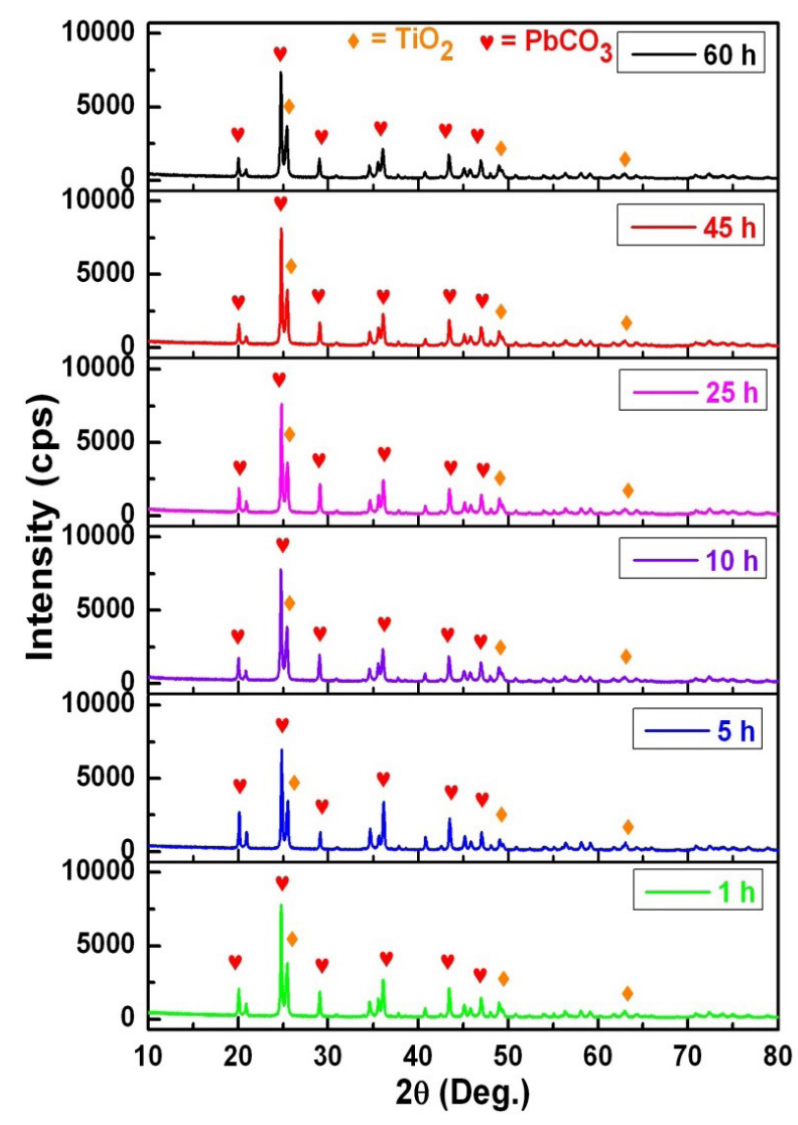

Figure 3: XRD patterns of $\mathrm{TiO}_{2}$ and $\mathrm{PbCO}_{3}$ mixture up to $60 \mathrm{~h}$ of milling.

The XRD investigations of $\mathrm{TiO}_{2}$ and $\mathrm{PbCO}_{3}$ powder mixture milled for $60 \mathrm{~h}$ and after different temperature and times of annealing treatment up to $1,000^{\circ} \mathrm{C}$ are shown in Figure 5.

At $500^{\circ} \mathrm{C}$ with a holding time of $1 \mathrm{~h}$, the single phase $\mathrm{PbTiO}_{3}$ has not yet been formed where there is still another phase present, $\mathrm{Pb}_{5} \mathrm{C}_{3} \mathrm{H}_{2} \mathrm{O}_{12}$. Single phase $\mathrm{PbTiO}_{3}$ with tetragonal perovskite crystal structure was formed after annealing at $600^{\circ} \mathrm{C}$ up to $1,000^{\circ} \mathrm{C}$ in $1 \mathrm{~h}$. XRD pattern of the sample which has undergone annealing process at $600^{\circ} \mathrm{C}$ for $1 \mathrm{~h}$ matched with the data based on the diffraction pattern on ICSD number 98-009-0693. The lattice constant calculated from the XRD data is $a=b=3.9116 \AA$ and $c=4.0943 \AA$. The structure matches with the $\mathrm{PbTiO}_{3}$ that can be used in various applications. Based on the XRD patterns in Figure 5, the average size of crystallites of each phase can be found, where the result is shown in Figure 6. 


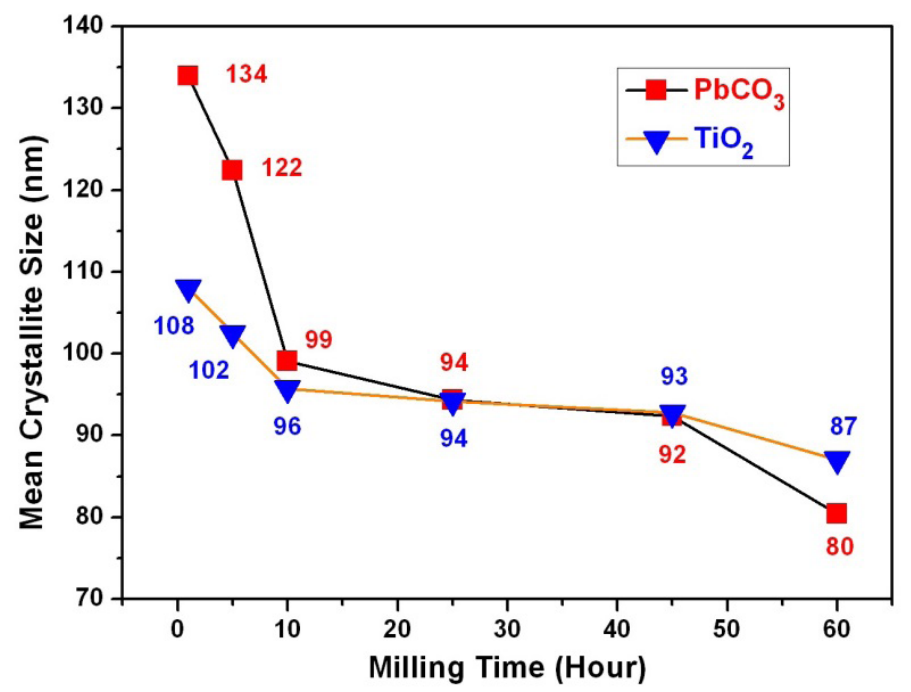

Figure 4: The mean crystallite size of $\mathrm{TiO}_{2}$ and $\mathrm{PbCO}_{3}$ mixture up to $60 \mathrm{~h}$ of milling.

To support the result, the temperature and time of the most optimum were achieved in the transformation process into a single phase $\mathrm{PbTiO}_{3}$ phase in full, then tested with thermal analysis. The intensity and sharpness of the XRD peaks of $\mathrm{PbTiO}_{3}$ phase were found to increase with annealing temperature at $600^{\circ} \mathrm{C}$ up to $1,000^{\circ} \mathrm{C}$. Based on Figure 6, it can be concluded that the average size of crystallites $\mathrm{PbTiO}_{3}$ increased exponentially with the rising annealing temperature. The increase in intensity and sharpness of the XRD peaks with annealing temperature may be attributed to the increase in the grain or crystallite size thereby increasing packing density of the samples annealed at higher temperature. 


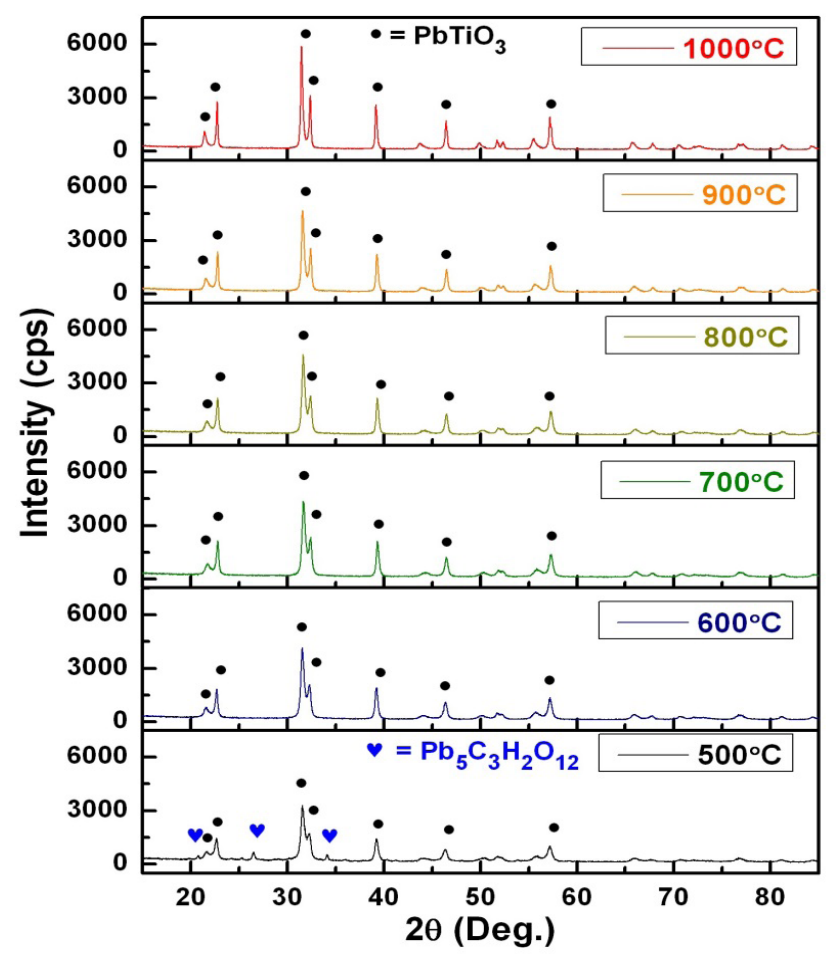

Figure 5: XRD profile of $\mathrm{TiO}_{2}$ and $\mathrm{PbCO}_{3}$ mixture after annealing up to $1,000^{\circ} \mathrm{C}$.

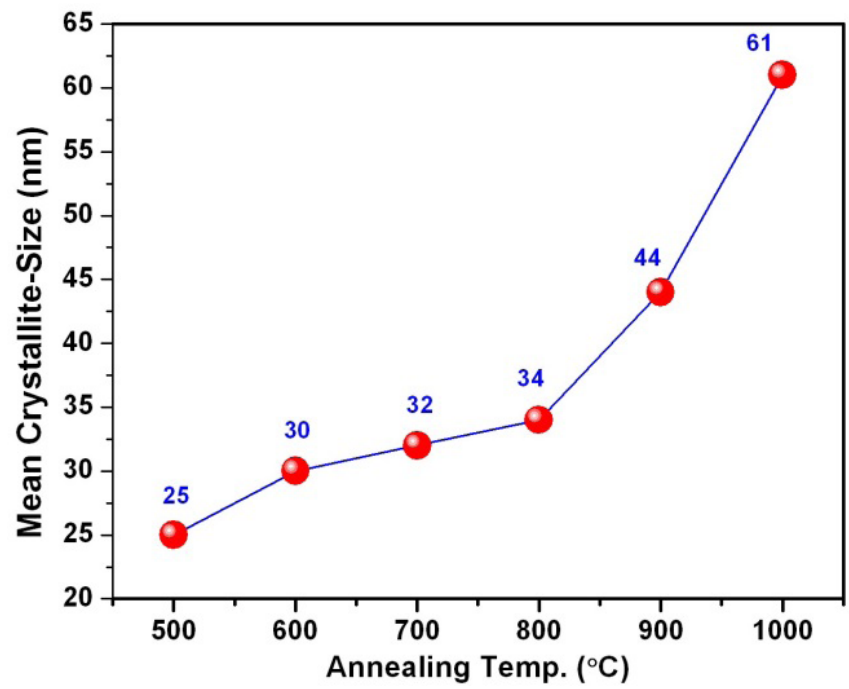

Figure 6: The mean crystallite size of $\mathrm{PbTiO}_{3}$. 


\section{CONCLUSION}

Tests on a mixture of $\mathrm{TiO}_{2}$ and $\mathrm{PbCO}_{3}$ as a piezoelectric material, $\mathrm{PbTiO}_{3}$, after undergoing a process of milling and sintering, concluded that mechanical alloying process for $60 \mathrm{~h}$ in a mixture of $\mathrm{TiO}_{2}+\mathrm{PbCO}_{3}$ caused the mixture of the two compounds to decrease their average particle size to $0.8 \mu \mathrm{m}$ and a crystallite size of $87 \mathrm{~nm}$ and $80 \mathrm{~nm}$, respectively. The reduction of the size of particle and crystallite was the result of the continuous collision between sample powder and ball mill. As a consequence, the samples underwent embrittlement and deformation. Another conclusion that can be reported is that $\mathrm{PbTiO}_{3}$ ceramic has been prepared by conventional solid-state reaction processing technique. The as-fired powder was found to be amorphous and crystallised to tetragonal $\mathrm{PbTiO}_{3}$ after annealing at $600^{\circ} \mathrm{C}$ up to $1,000^{\circ} \mathrm{C}$ for $1 \mathrm{~h}$. The crystallite size of $\mathrm{PbTiO}_{3}$ increases as a function of temperature of annealing process.

\section{ACKNOWLEDGEMENTS}

We sincerely thank the Indonesian Ministry of Research, Technology and Higher Education that fully supported this study via the Competitive Research Grant (Hibah Bersaing) Daftar Isian Pelaksanaan Anggaran (DIPA) under reference no. 042.06.1.401516/2016.

\section{REFERENCES}

1. Gene, H. H. (1999). Ferroelectric ceramics: History and technology. J. Am. Ceram. Soc., 82(4), 797-818, https://doi.org/10.1111/j.1151-2916.1999. tb01840.x.

2. Cohen, R. E. (1992). Origin of ferroelectricity in perovskite oxides. Nature, 358(6382), 136-138.

3. Pardo, L. et al. (1999). Ferroelectric materials based on lead titanate. In Nalwa, H. S. (Ed). Handbook of low and high dielectric constant materials and their applications. Jakarta: Academic Press.

4. Ricote, J. et al. (2004). Application of the X-ray combined analysis to the study of lead titanate based ferroelectric thin films. Thin Solid Films, 450(1), 128-133, https://doi.org/10.1016/j.tsf.2003.10.056.

5. Bhatti, H. S. et al. (2016). Synthesis and induced multiferroicity of perovskite PbTiO3: A review. Appl. Surf. Sci., 367, 291-306, https://doi.org/10.1016/j. apsusc. 2016.01.164. 
6. Wang, D. G. et al. (2008). Lead-based titanate ferroelectric thin films fabricated by a sol-gel technique. Appl. Surf. Sci., 255, 1637-1645, https:// doi.org/10.1016/j.apsusc.2008.09.053.

7. Vijendra, A. C. \& Govind, K. B. (2013). Synthesis, structure and electrical properties of pure $\mathrm{PbTiO}_{3}$ ferroelectric ceramics. Smart Mater. Res., 1-9, http://dx.doi.org/10.1155/2013/147524.

8. Ahmad, T. \& Ashok, K. G. (2006). Reverse micellar route to nanocrystalline titanate $\left(\mathrm{SrTiO}_{3}, \mathrm{SrTiO}_{4}\right.$, and $\left.\mathrm{PbTiO}_{3}\right)$ : Structural aspects and dielectric properties. J. Am. Ceram. Soc., 89(4), 1326-1332, https://doi.org/10.1111/ j.1551-2916.2005.00886.x.

9. Fang, J. et al. (2002). Comparative study on phase development of lead titanate powders. Mater. Lett., 52, 304-312, https://doi.org/10.1016/S0167577X(01)00411-6.

10. Fang, J. et al. (1999). Preparation and characterisation of ultrafine lead titanate $\left(\mathrm{PbTiO}_{3}\right)$ powders. J. Mater. Sci., 34, 1943-1952, https://doi.org/ 10.1023/A:1004596217129.

11. Jangade, P., Arjunwadkar, P. R. \& Nagarbawadi, M. A. (2016). Structural characterization of lead titanate $\left(\mathrm{PbTiO}_{3}\right)$ sample using FULLPROF. IOSR $J$. Appl. Phys., 8(6), 52-60, https://doi.org/10.9790/4861-0806055760.

12. Kim, S., Jun, M. C. \& Hwang, S. C. (1999). Preparation of undoped lead titanate ceramics via sol-gel processing. J. Am. Ceram. Soc., 82(2), 289296, https://doi.org/10.1111/j.1551-2916.1999.tb20060.x.

13. Zhu, J. et al. (2014). Pressure-induced reversal between thermal contraction and expansion in ferroelectric $\mathrm{PbTiO}_{3}$. Scient. Rep., 4, 3700, https://doi. org/10.1038/srep03700.

14. Kvasov, A. et al. (2016). Piezoelectric enhancement under negative pressure. Nature Comm., 7, 12136, https://doi.org/10.1038/ncomms12136.

15. Yan, Y. et al. (2016). Giant piezoelectric voltage coefficient in grain-oriented modified $\mathrm{PbTiO}_{3}$ material. Nature Comm., 7, 13089, https://doi.org/10.1038/ ncomms 13089 .

16. Sverre, M. S. et al. (2007). Decomposition and crystallization of a sol-gelderived $\mathrm{PbTiO}_{3}$ precursor. J. Am. Ceram. Soc., 90(8), 2649-2652, https:// doi.org/10.1111/j.1551-2916.2007.01789.x.

17. Palkar, V. R., Purandare, S. C. \& Pinto, R. (1999). Ferroelectric thin films of $\mathrm{PbTiO}_{3}$ on silicon. J. Phys. D Appl. Phys., 32, 1-18.

18. Yadav, H. O. (2004). Optical and electrical properties of sol-gel derived thin films of $\mathrm{PbTiO}_{3}$. Ceram. Int., 30(7), 1493-1498, https://doi.org/10.1016/j. ceramint.2003.12.133.

19. Rodel, J. et al. (2009). Perspective on development of lead-free piezoceramics. J. Am. Ceram. Soc., 92(6), 1153-1177. 
20. Rujiwatra, A., Jongphiphan, J. \& Ananta, S. (2005). Stoichiometric synthesis of tetragonal phase pure lead titanate under mild chemical conditions employing $\mathrm{NaOH}$ and $\mathrm{KOH}$. Mater. Lett., 59, 1871-1875, https://doi. org/10.1016/j.matlet.2005.02.002.

21. Zhang, S. \& Yu, F. (2011). Piezoelectric materials for high temperature sensor. J. Am. Ceram. Soc., 94(10), 3153-3170, https://doi.org/10.1111/ j.1551-2916.2011.04792.x.

22. Zhang, S. et al. (2013). Piezoelectric property of relaxor- $\mathrm{PbTiO}_{3}$ crystals under uniaxial transverse stress. Appl. Phys. Lett., 102, 172902, https://doi. org/10.1063/1.4803183.

23. Gelabert, M. C., Gersten, B. L. \& Riman, R. E. (2000). Hydrothermal synthesis of lead titanate from complexed precursor solutions. J. Cryst. Growth, 211(1-4), 497-500, https://doi.org/10.1016/S0022-0248(99)007812.

24. Morita,T. \& Cho, Y. (2006). Piezoelectric property of an epitaxial lead titanate thin film deposited by the hydrothermal method. Appl. Phys. Lett., 88, 112908, https://doi.org/10.1063/1.2183364.

25. Zeng, X. et al. (2002). Preparation of nanocrystalline $\mathrm{PbTiO}_{3}$ by accelerated sol-gel process. Mater. Chem. Phys., 77, 209-214, https://doi.org/10.1016/ S0254-0584(01)00558-2.

26. $\mathrm{Wu}, \mathrm{Y}$. J. et al. (2010). Densification and microstructures of $\mathrm{PbTiO}_{3}$ ceramics prepared by spark plasma sintering. Mater. Sci. Eng. A, 527, 5157-5160, https://doi.org/10.1016/j.msea.2010.04.096.

27. Wang, J. et al. (2005). Sonochemical preparation of $\mathrm{PbTiO}_{3}$ fine powders. J. Am. Ceram. Soc., 88(1), 34-37, https://doi.org/10.1111/j.15512916.2004.00015.x.

28. Udomporn, A. \& Ananta, S. (2004). Effect of calcination condition on phase formation and particle size of lead titanate powders synthesized by the solid-state reaction. Mater. Lett., 58, 1154-1159, https://doi.org/10.1016/j. matlet.2003.08.028.

29. Wongmaneerung, R., Yimnirun, R. \& Ananta, S. (2006). Effects of milling time and calcination condition on phase formation and particle size of lead titanate nanopowders prepared by vibro-milling. Mater. Lett., 60, 26662671, https://doi.org/10.1016/j.matlet.2006.01.062.

30. Wongmaneerung, R., Yimnirun, R. \& Ananta, S. (2006). Effect of vibromilling time on phase formation and particle size oflead titanate nanopowders. Mater. Lett., 60, 1447-1452, https://doi.org/10.1016/j.matlet.2005.11.043.

31. Stankus, V. \& Dudonis, J. (2004). Lead titanate thin film synthesis by solidstate reactions. Mater. Sci. Eng. B, 109, 178-182, https://doi.org/10.1016/j. mseb.2003.10.047. 
32. Xue, J., Wan, D. \& Wang, J. (1999). Mechanochemical synthesis of nanosized lead titanate powders from mixed oxides. Mater. Lett., 39, 364-369, https:// doi.org/10.1016/S0167-577X(99)00036-1.

33. Somiya, Y., Bhalla, A. S. \& Cross, L. E. (2001). Study of (Sr, $\mathrm{Pb}) \mathrm{TiO}_{3}$ ceramics on dielectric and physical properties. Int. J. Inorg. Mater., 3, 709714, https://doi.org/10.1016/S1466-6049(01)00187-8.

34. Forrester, J. S. et al. (2004). Synthesis of $\mathrm{PbTiO}_{3}$ ceramics using mechanical alloying and solid state sintering. J. Solid State Chem., 177, 3553-3559, https://doi.org/10.1016/j.jssc.2004.06.005.

35. Udomporn, A. \& Ananta, S.(2004). The phase formation of lead titanate powders prepared by solid-state reaction. Curr. Appl. Phys., 4, 186-188, https://doi.org/10.1016/j.cap.2003.11.005.

36. Chattopadhyay, S. et al. (1995). Size-induced diffuse phase transition in the nanocrystalline ferroelectric $\mathrm{PbTiO}_{3}$. Phys. Rev. B, 52, 13177, https://doi. org/10.1103/ PhysRevB.52.13177.

37. Williamson, G. K. \& Hall, W. H. (1953). X-ray line broadening from filed aluminium and wolframL'elargissement des raies de rayons $\mathrm{x}$ obtenues des limailles d'aluminium et de tungsteneDie verbreiterung der roentgeninterferenzlinien von aluminium- und wolframspaenen. Acta Metal., 1, 22-31, https://doi.org/10.1016/0001-6160(53)90006-6.

38. Lü, L. \& Lai, M. O. (1998). Mechanical alloying, vol. 4. Boston: Kluwer.

39. Suryanarayana, C. (2004). Mechanical alloying and milling. New York: Marcel Dekker. 